\title{
The Impact of Alpha-lipoic Acid Dietary Supplementation on Growth Performance, Liver and Bone Efficiency, and Expression Levels of Growth-Regulating Genes in Commercial Broilers
}

\author{
Osama A. Sakr ${ }^{1}$, Eldsoky Nassef ${ }^{2}$, Sabreen E. Fadl ${ }^{3 *}$, Hazem Omar $^{4}$, Emad Waded ${ }^{5}$, and Seham El-Kassas ${ }^{6}$

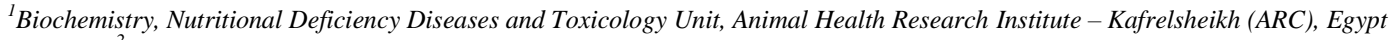 \\ ${ }^{2}$ Nutrition and Clinical Nutrition Department, Faculty of Veterinary Medicine, Kafrelsheikh University, Egypt. \\ ${ }^{3}$ Biochemistry Dept., Faculty of Veterinary Medicine, Matrouh University, Matrouh, Egypt. \\ ${ }^{4}$ Pharmacology Department, Faculty of Veterinary Medicine, Kafrelsheikh University, Egypt. \\ ${ }^{5}$ Clinical Pathology Department, Faculty of Veterinary Medicine, Kafrelsheikh University, Egypt. \\ ${ }^{6}$ Animal, Poultry and Fish Breeding and Production, Department of Animal Wealth Development, Faculty of Veterinary Medicine, Kafrelsheikh University, Egypt \\ *Corresponding author's Email: nourmallak@yahoo.com; ORCID: 0000-0001-5541-6159
}

Received: 29 Jan. 2020

Accepted: 09 Mar. 2020

\begin{abstract}
Increasing bird growth is a crucial demand for all poultry producers. This occurs by the genetic improvement of the existing breeds and by improving the feeding management. The present study investigated the impact of AlphaLipoic Acid (ALA) supplementation in the diet on performance, serum parameters, tibia bone composition, and the expression levels of growth-related genes in chickens. A total of 120 day-old broiler chicks (Cobb 505) were used and divided into four groups. The control group was fed on a basal diet without the ALA supplement. The birds in groups of A50, A100, and A200 were fed on the formulated diet supplemented with ALA at doses of 50, 100, and $200 \mathrm{mg} / \mathrm{kg}$ of diet, respectively for 35 days. Results indicated that ALA supplementation significantly improved the birds' growth performance. This effect was associated with a marked upregulation of mRNA levels of GHR and IGFR and a significant downregulation of MSTN expression level. In addition, the ALA dietary provision caused a distinct improvement in liver function and bone efficiency. Thus, the improving effect of ALA on birds' growth performance is mediated by modulating the growth-regulating genes. In conclusion, ALA could be used as a good growth-promoter in dietary supplements.
\end{abstract}

Keywords: Alpha-lipoic Acid; Bone Efficiency; Broilers; Gene Expression; Growth Performance.

\section{INTRODUCTION}

Increasing bird's growth is a crucial demand for all poultry producers. This occurs by the genetic improvement of the existing breeds and by improving the feeding management (Petracci and Cavani, 2012). The latter is achieved through the dietary provision of feed additives such as antioxidants, enzymes, organic acids, probiotics, prebiotics and synbiotics along with herbal extracts to enhance the bird's growth performance and meat quality (Sohaib et al., 2018). Alpha-lipoic acid (ALA) is an effective multifunction feed additive and its use ranges from therapeutic applications to the dietary supplementations. It is widely dispensed in foods and has both water and fatsoluble properties thus it is absorbed from the diet (Packer et al., 1995). After absorption, ALA passes through cell membranes, leading to nutrient availability (Kofuji et al., 2008).

ALA plays an important role in energy metabolism as a result of its functions as a cofactor in many reactions that produce energy ( $\mathrm{Li}$ et al., 2014). Thus, its dietary provision to farm animals, particularly broiler chickens, along with the cell produced it naturally in small quantity, directly scavenges free radicals and enhances fatty acid mobilization and energy expenditure. Therefore, it has a promoting effect on growth and the immune system, as well as decreases inflammation and oxidative stress (Sohaib et al., 2018). Recently, the application of ALA in broilers' diet is widespread to promote growth and improve the quality of carcass meat. It regulates the birds' growth performance by promoting energy metabolism and improving antioxidant status and immune response (Bai et al., 2012). To cite this paper: Sakr OA, Nassef E, Fadl SE, Omar H, Waded E, and El-Kassas S (2020). The Impact of Alpha-lipoic Acid Dietary Supplementation on Growth Performance,
Liver and Bone Efficiency, and Expression Levels of Growth-Regulating Genes in Commercial Broilers. J. World Poult. Res., 10 (2S): 172-179. DOI: https://dx.doi.org/10.36380/jwpr.2020.22 
ALA also protects liver of the broiler from damage as a result of chronic exposure to the low dose of aflatoxin B1 through improvement of plasma total protein, albumin, alkaline phosphatase, and the activities of alanine aminotransferase (ALT) and aspartate aminotransferase (AST) (Li et al., 2014). The aim of the present study was to evaluate the effect of ALA on performance, the liver and bone efficiency, and expression level of growthrelated genes in chicken broilers.

\section{MATERIALS AND METHODS}

\section{Ethical approval}

The current study was approved by the Ethical Committee for live birds sampling at the Animal Health Research Institute, Egypt (License No. AHRI 35429).

\section{Birds and experimental design}

120 one-day-old chicks (Cobb-505 broiler strain) were used in the present study. Chicks were gained from a local farm and housed in the room. The room was cleaned and well-ventilated where the chicks were kept under good sanitation and hygienic management. The feed and water were available ad libitum. Chicks were allotted into four groups randomly with average body weight $=51.72 \pm 0.17$ $\mathrm{g} /$ chick. For each treatment, 3 replicates contained 10 chicks were used. The $\mathrm{C}$ group (control one) was fed on a basal diet (Table 1). The basal diet was prepared according to broiler nutrition specification, 2007. The A50, A100, and A200 were fed on the formulated diet supplemented with ALA (Thiotacid ${ }^{\circledR}=$ It is an antioxidant made in EVA PHARMA Company, Egypt, in the form of tablets, each tablet contains $600 \mathrm{mg}$ ALA) in a dose of 50, 100, and 200 $\mathrm{mg} / \mathrm{kg}$ diet, respectively. All birds were weighed at the starting of the design and every week for five weeks while the diet was weighed every day to determine the feed intake and calculate the feed conversion ratio (FCR).

\section{Sample collection and measurements of serum parameters}

After 5 weeks, six birds from each group ( 2 birds/ replicate) were randomly selected and slaughtered to collect the blood samples. After the coagulation of blood, the serum samples were separated (centrifugation at 3000 rpm for $15 \mathrm{~min}$ ) and kept at $-20{ }^{\circ} \mathrm{C}$. The serum was used to determine total protein, albumin, ALT, AST, and Alkaline phosphatase which were estimated using commercial kits (Bio-Diagnostic Company). While globulin was calculated by mathematical subtraction of albumin value from that of the total protein.

\section{Measurement of tibia bone composition}

After slaughtering, the left tibia bone of each slaughtered bird was isolated. The bones were dried in hot air oven at $60{ }^{\circ} \mathrm{C}$ for $48 \mathrm{hr}$ to determine DM and moisture contents. The dried bones were finely ground and incinerated in the muffle furnace at $600{ }^{\circ} \mathrm{C}$ for $2 \mathrm{hr}$ to determine ash content according to AOAC (2019). Calcium and phosphorus contents of tibia ash were determined by atomic absorption spectrometry.

Table 1. Ingredients and nutrients composition of the basal diets.

\begin{tabular}{|c|c|c|c|}
\hline \multirow{2}{*}{ Ingredients (\%) } & \multicolumn{3}{|c|}{ Diets } \\
\hline & $\begin{array}{c}\text { Starter } \\
\text { (0-10 days) }\end{array}$ & $\begin{array}{c}\text { Grower } \\
\text { (11-24 days) }\end{array}$ & $\begin{array}{c}\text { Finisher } \\
\text { (25 day- } \\
\text { slaughter) }\end{array}$ \\
\hline Yellow Corn & 58.0 & 63 & 66 \\
\hline Soybean meal (48\%) & 30.0 & 25 & 25 \\
\hline $\begin{array}{l}\text { Corn gluten meal } \\
(60 \%)\end{array}$ & 6.1 & 6.1 & 2.5 \\
\hline Soy oil & 1.5 & 2.1 & 3 \\
\hline $\begin{array}{l}\text { Monocalcium } \\
\text { phosphate }^{1}\end{array}$ & 1.85 & 1.6 & 1.5 \\
\hline Limestone $^{2}$ & 1.12 & 0.95 & 0.9 \\
\hline Lysine $^{3}$ & 0.45 & 0.35 & 0.2 \\
\hline DL-Methionine $^{4}$ & 0.25 & 0.2 & 0.2 \\
\hline Common salt & 0.43 & 0.4 & 0.4 \\
\hline Premix $^{1}$ & 0.3 & 0.3 & 0.3 \\
\hline \multicolumn{4}{|l|}{ Nutrients composition } \\
\hline $\mathrm{ME}(\mathrm{Kcal} / \mathrm{Kg})$ & 3084 & 3176 & 3215 \\
\hline Crude protein $\%$ & 23.2 & 21.14 & 19.0 \\
\hline Lysine \% & 1.44 & 1.23 & 1.09 \\
\hline Methionine & 0.68 & 0.6 & 0.54 \\
\hline Methionine \& Cysteine & 1.06 & 0.96 & 0.86 \\
\hline Calcium & 1.08 & 0.91 & 0.87 \\
\hline Available phosphorus & 0.5 & 0.45 & 0.42 \\
\hline Sodium & 0.2 & 0.18 & 0.18 \\
\hline \multicolumn{4}{|c|}{$\begin{array}{l}{ }^{1} \text { Premix provides Vit A (12000 Iu), Vit D (5000 Iu), Vit E (50 mg), Vit } \\
\mathrm{K} 3(3 \mathrm{mg}) \text {, Vit B1 }(3 \mathrm{mg}) \text {, Vit B2 }(8 \mathrm{mg}) \text {, Vit B6 }(4 \mathrm{mg}) \text {, Vit B12 }(0.016 \\
\mathrm{mg}) \text {, nicotinic acid }(60 \mathrm{mg}) \text {, pantothinic acid }(15 \mathrm{mg}) \text {, folic acid }(2 \mathrm{mg}) \text {, } \\
\text { biotin }(0.2 \mathrm{mg}) \text {, iron }(40 \mathrm{mg}) \text {, copper }(16 \mathrm{mg}) \text {, zinc }(100 \mathrm{mg}) \text {, manganese } \\
(120 \mathrm{mg}) \text {, iodine }(1.25 \mathrm{mg}) \text {, selenium }(0.3 \mathrm{mg}) \text { per } 1 \mathrm{~kg} \text { diet. }\end{array}$} \\
\hline
\end{tabular}

\section{Real-time polymerase chain reaction Sample collection}

From each treated group, six muscle samples (one sample/bird) were collected from the slaughtered birds and used for the gene expression analysis. The muscle samples were gathered into clean Eppendorf tubes, quickly frozen in liquid nitrogen then stored $\left(-80^{\circ} \mathrm{C}\right)$ until use.

\section{Total RNA extraction and cDNA synthesis}

Total RNA from muscle samples was extracted using easy RED total RNA extraction kits (Cat. No. 17063, Intron Biotechnology, Inc.) according to the manufacturer's instructions. Briefly, about $30 \mathrm{mg}$ of muscle samples were ground into liquid nitrogen using a mortar and pestle. Then, $1 \mathrm{ml}$ of easy RED and $200 \mu \mathrm{l}$ chloroform were added, followed by centrifugation at 
maximum speed $(20817 \mathrm{xg})$. After that, RNA was pelleted and eluted in RNase free water (El-Kassas et al., 2016). RNA integrity was verified by agarose gel electrophoresis. A fixed concentration of RNA $(2 \mu \mathrm{g})$ was reverse transcribed using the SensiFAST ${ }^{\text {TM }}$ cDNA synthesis kit (Bioline, United Kingdom).

\section{qRT-PCR assay}

Specific primers (Table 2) were used to amplify GHR: growth hormone receptor, IGFIR: Receptor of insulin-like growth factor 1, and MSTN: Myostatin using the $\beta$ actin as a housekeeping (internal standard) gene. The qPCR reaction mix, for each gene, contained $10 \mu \mathrm{l}$ of SensiFast ${ }^{\mathrm{TM}}$ SYBR Lo-Rox master mix (Bioline, United Kingdom), $0.5 \mu \mathrm{M}$ of each primer and $2 \mu 1$ of cDNA. The qPCR assay for each tested gene was done in duplicate using Stratagene MX300P real-time PCR system (Agilent Technologies) with thermal cycling conditions were: initial denaturation at $95^{\circ} \mathrm{C}$ for 15 minutes, followed by 40 cycles at $95^{\circ} \mathrm{C}$ for 15 seconds, annealing for 1 minute at $60^{\circ} \mathrm{C}$ for all genes. The dissociation curves were analyzed showing only one peak at a specific melting temperature for all tested genes indicating specifically amplified PCR products. The relative mRNA expression level for each gene was calculated using the $2^{-\Delta \Delta \mathrm{ct}}$ method as described by Livak and Schmittgen (2001). In this context, the fold change for each gene was normalized against the housekeeping gene ( $\beta$ actin) and its comparable values of the control group (feeding basal diet without ALA supplementation).

\section{Statistical analysis}

The statistical analysis of data was performed using SPSS version 20. One-way ANOVA was used to test the effect of supplementing ALA into the birds' diet. The statistical significance at p-value $<0.05$ between different supplemented groups was determined based on Duncan's test. The results were presented as mean \pm SEM. For gene expression data, differences were considered to be statistically significant at $\mathrm{p}$-values $<0.05$

\section{RESULTS}

\section{Growth performance}

Statistical analysis of the data represented in Table (3) revealed that ALA supplementation (group A50, A100, and A200) significantly $(\mathrm{p} \leq 0.05)$ increase the final body weight, body weight gain, and average daily gain when compared with the control group. Also, statistical analysis of the FCR data indicated that the inclusion rate of ALA (group A50, A100, and A200) significantly $(\mathrm{p} \leq 0.05)$ improved FCR results when compared with the control group.

\section{Serum liver function}

Effect of dietary ALA supplementation on serum liver function of broiler chicken is presented in Table 4 . Statistical analysis of the obtained result revealed that ALA supplementation (group A50, A100, and A200) significantly decreased $(\mathrm{p} \leq 0.05)$ serum ALT, AST, and AKP when compared with the control group. On the other hand, statistical analysis of the obtained data indicated that the inclusion rate of ALA (group A50, A100, and A200) significantly increased $(\mathrm{p} \leq 0.05)$ serum proteins when compared with the control group.

\section{Tibia bone characteristics}

Results of tibia bone analysis are shown in Table 5. Dietary supplementation of ALA (group A50, A100, and A200) significantly increased $(\mathrm{P} \leq 0.05)$ dry matter and ash contents in tibia bone of broiler chickens as compared to the control group. Broilers fed $100 \mathrm{mg}$ ALA $/ \mathrm{kg}$ diet significantly increased $(\mathrm{P} \leq 0.05)$ calcium concentration in tibia bone when compared with the control group. Moreover, there was no significant difference in phosphorus concentration in tibia bone among all groups.

\section{Expression levels of growth-related gene}

Supplementing ALA into the birds' diet significantly modified the relative mRNA transcript levels of $G H R$, $I G F 1 R$, and MSTN compared to their expressions in the case of birds fed basal diet $(\mathrm{P}=0.009, \mathrm{P}=0.03$, and $\mathrm{P}=$ 0.026, respectively). For GHR (Figure 1), ALA supplementation at $50 \mathrm{mg} / \mathrm{kg}$ diet stimulated a significant increase of GHR mRNA transcript levels $(\mathrm{P}=0.002)$. Interestingly, increasing the level of ALA supplementation to $100 \mathrm{mg} / \mathrm{kg}$ diet significantly increased $G H R$ gene expression level $(\mathrm{P}=0.014)$ but less than that in the case of $50 \mathrm{mg} / \mathrm{kg}$ diet supplementation. It resulted in an only 1.9fold increase of the relative $G H R$ gene expression level compared to 2.99-fold in the case of A 50 group. However, the ALA dietary provision at $200 \mathrm{mg} / \mathrm{kg}$ diet was able to markedly upregulate the $G H R$ gene expression level $(\mathrm{P}=0.004)$. It resulted in 4.1 -fold higher than that of non-supplemented birds $(\mathrm{C})$.

For IGFIR gene expression (Figure 2), ALA stimulated a dose-dependent increase in $I G F I R$ relative gene expression level. When it was added at $50 \mathrm{mg} / \mathrm{kg}$ diet, it induced a non-significant increase (2.03 fold) of IGFIR expression level. While, duplicating the ALA supplementing dose into the birds' diet to 100 and 200 
$\mathrm{mg} / \mathrm{kg}$ diet caused a distinct upregulation to IGFIR mRNA expression level $(\mathrm{P}=0.009$ and $\mathrm{P}=0.013$, respectively). It stimulated 3.58- and 3.74-fold increases of $I G F 1 R$, respectively. The MSTN mRNA copies were also modulated following ALA dietary provision (Figure 3). Its supplementation at $50 \mathrm{mg} / \mathrm{kg}$ diet significantly decreased the relative MSTN mRNA level $(\mathrm{P}<0.001)$. It resulted in 0.1-fold compared to the non-supplemented group (C). Also, ALA addition into birds' diet at 100 $\mathrm{mg} / \mathrm{kg}$ diet resulted in a significant downregulation of MSTN gene expression level $(\mathrm{P}<0.001)$. It only caused 0.06-fold of MSTN mRNA copies. Additionally, birds fed ALA at $200 \mathrm{mg} / \mathrm{kg}$ diet showed a distinct reduction of MSTN expression level compared to those fed only basal diet without ALA supplementation $(\mathrm{P}<0.001)$. In summary, ALA dietary provision upregulated the gene expression levels of $I G F I R$ and $G H R$ genes and downregulated the MSTN mRNA level.

Table 2. Primer sequences used in qPCR analysis

\begin{tabular}{lcr}
\hline Primer & Sequence & Reference \\
\hline $\begin{array}{l}\text { - actin } \\
\text { IGF1R }\end{array}$ & $\begin{array}{c}\text { Forward- 5' TACCTGAGCGCAAGTACTCTGCT 3' } \\
\text { Reverse- 5' CATCGTACTCCTGCTTGCTGAT 3' }\end{array}$ & (El-Kassas et al., 2018) \\
\hline \multirow{2}{*}{ MSTN } & $\begin{array}{r}\text { Forward -5'GATCGGGCTTCACAACTT 3' } \\
\text { Reverse -5'CCTTCGGAGGCTTATTTC 3' }\end{array}$ & (Chen et al., 2011) \\
\hline GHR & $\begin{array}{c}\text { Forward or-5'GCAAAAGCTAGCAGTCTATG 3' } \\
\text { Reverse -5' TCCGTCTTTTTCAGCGTTCT3' }\end{array}$ & (Dushyanth et al., 2016) \\
\hline
\end{tabular}

IGF1R: Receptor of insulin like growth factor 1, MSTN: Myostatin, GHR: growth hormone receptor.

Table 3. Effect of dietary ALA on growth performance of broiler chickens.

\begin{tabular}{|c|c|c|c|c|}
\hline Item & Control & $\mathbf{A 5 0}$ & $\mathbf{A 1 0 0}$ & $\mathbf{A 2 0 0}$ \\
\hline Initial weight (g) & $51.79 \pm 0.56$ & $52.06 \pm 0.63$ & $51.49 \pm 0.69$ & $51.62 \pm 0.57$ \\
\hline Final weight $(\mathrm{g})$ & $1706.8 \pm 17.2^{b}$ & $1753.2 \pm 14.0^{\mathrm{a}}$ & $1768.6 \pm 14.8^{a}$ & $1754.8 \pm 11.8^{\mathrm{a}}$ \\
\hline Body weight gain (g) & $1655.0 \pm 16.1^{\mathrm{b}}$ & $1701.1 \pm 13.2^{\mathrm{a}}$ & $1717.1 \pm 13.3^{\mathrm{a}}$ & $1703.2 \pm 10.5^{\mathrm{a}}$ \\
\hline Average daily gain (g) & $47.29 \pm 0.46^{b}$ & $48.6 \pm 0.38^{\mathrm{a}}$ & $49.06 \pm 0.38^{\mathrm{a}}$ & $48.66 \pm 0.30^{\mathrm{a}}$ \\
\hline Feed intake $(\mathrm{g})$ & $2961.8 \pm 6.1$ & $2975.4 \pm 7.5$ & $3002.4 \pm 9.2$ & $2969.2 \pm 6.3$ \\
\hline Feed conversion ratio & $1.79 \pm 0.07^{\mathrm{b}}$ & $1.75 \pm .09^{\mathrm{a}}$ & $1.75 \pm 0.05^{\mathrm{a}}$ & $1.74 \pm 0.03^{\mathrm{a}}$ \\
\hline
\end{tabular}

ALA: alpha-lipoic acid. Control group received $0 \mathrm{mg}$ ALA/kg diet, A50 group received 50mg ALA/kg diet, A100 group received 100mg ALA/kg diet, and A200 group received $200 \mathrm{mg}$ ALA $/ \mathrm{kg}$ diet. Values are expressed as mean \pm standard errors. Means with different superscript letters within the same row indicates significant difference at $(\mathrm{p} \leq 0.05)$.

Table 4. Serum liver function of broiler chicken supplemented with ALA at 35 days.

\begin{tabular}{lcccc}
\hline Parameters & Control & A50 & A100 & A200 \\
\hline ALT (u/l) & $9.2 \pm 0.416^{\mathrm{a}}$ & $7 \pm 0.577^{\mathrm{b}}$ & $6.667 \pm 0.330^{\mathrm{b}}$ & $6.666 \pm 0.882^{\mathrm{b}}$ \\
AST (u/l) & $185.2 \pm 0.723^{\mathrm{a}}$ & $182.1 \pm 0.493^{\mathrm{b}}$ & $181.667 \pm 0.882^{\mathrm{b}}$ & $179.704 \pm 0.788^{\mathrm{b}}$ \\
AKP (Iu/l) & $17.333 \pm 0.881^{\mathrm{a}}$ & $13.323 \pm 0.89^{\mathrm{b}}$ & $11.667 \pm 0.330^{\mathrm{bc}}$ & $11.000 \pm 0.577^{\mathrm{c}}$ \\
Total protein (g/dl) & $2.95 \pm 0.029^{\mathrm{c}}$ & $3.700 \pm 0.058^{\mathrm{b}}$ & $3.800 \pm 0.057^{\mathrm{b}}$ & $4.125 \pm 0.020^{\mathrm{a}}$ \\
Albumin (g/dl) & $1.33 \pm 0.020^{\mathrm{c}}$ & $1.62 \pm 0.017^{\mathrm{b}}$ & $1.510 \pm 0.015^{\mathrm{c}}$ & $1.653 \pm 0.044^{\mathrm{a}}$ \\
Globulin (g/dl) & $1.617 \pm 0.009^{\mathrm{d}}$ & $2.080 \pm 0.040^{\mathrm{c}}$ & $2.290 \pm 0.043^{\mathrm{b}}$ & $2.492 \pm 0.020^{\mathrm{a}}$ \\
\hline
\end{tabular}

ALA: alpha-lipoic acid. ALT: alanine aminotransferase, AST: aspartate aminotransferase, AKP: alkaline phosphatase. Control group received 0 mg ALA/kg diet, A50 group received 50mg ALA/kg diet, A100 group received 100mg ALA/kg diet, and A200 group received 200mg ALA/kg diet. Values are expressed as mean \pm standard errors. Means with different superscript letters within the same row indicates significant difference at $(\mathrm{p} \leq 0.05)$.

Table 5. Tibia bone composition of broiler chickens supplemented with ALA at 35 days.

\begin{tabular}{lcccc}
\hline Parameters & Control & A50 & A100 & \multicolumn{1}{c}{ A200 } \\
\hline Dry matter \% & $40.98 \pm 0.05^{\mathrm{b}}$ & $45.21 \pm 0.33^{\mathrm{a}}$ & $44.10 \pm 0.33^{\mathrm{a}}$ & $44.0 \pm 0.19^{\mathrm{a}}$ \\
Moisture \% & $59.02 \pm .0 .09^{\mathrm{a}}$ & $54.79 \pm 0.67^{\mathrm{b}}$ & $55.90 \pm 0.11^{\mathrm{b}}$ & $56.0 \pm 0.45^{\mathrm{b}}$ \\
Ash \% & $41.36 \pm 0.14^{\mathrm{b}}$ & $45.63 \pm 0.71^{\mathrm{a}}$ & $44.5 \pm 0.25^{\mathrm{a}}$ & $44.41 \pm 0.39^{\mathrm{a}}$ \\
Ca \% & $34.04 \pm 1.84^{\mathrm{b}}$ & $37.32 \pm 0.33^{\mathrm{ab}}$ & $39.0 \pm 1.18^{\mathrm{a}}$ & $37.7 \pm 1.25^{\mathrm{ab}}$ \\
P \% & $16.25 \pm 1.95$ & $18.7 \pm 1.92$ & $17.68 \pm 1.79$ & $19.38 \pm 1.37$ \\
\hline
\end{tabular}

ALA: alpha-lipoic acid. Control group received $0 \mathrm{mg}$ ALA/kg diet, A50 group received 50mg ALA/kg diet, A100 group received 100mg ALA/kg diet, and A200 group received $200 \mathrm{mg} \mathrm{ALA} / \mathrm{kg}$ diet. Values are expressed as mean \pm standard errors. Means with different superscript letters within the same row indicates significant difference at $(\mathrm{p} \leq 0.05)$. 


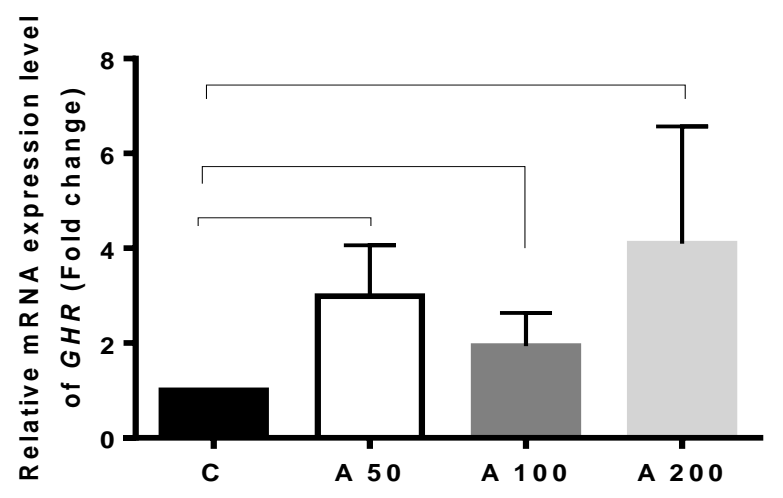

Figure 1. Relative mRNA expression level of GHR (fold change).C group received $0 \mathrm{mg}$ alpha-lipoic acid (ALA) $/ \mathrm{kg}$ diet, A50 group received 50mg ALA $/ \mathrm{kg}$ diet, A100 group received $100 \mathrm{mg} \mathrm{ALA} / \mathrm{kg}$ diet, and A200 group received 200mg ALA/kg diet.

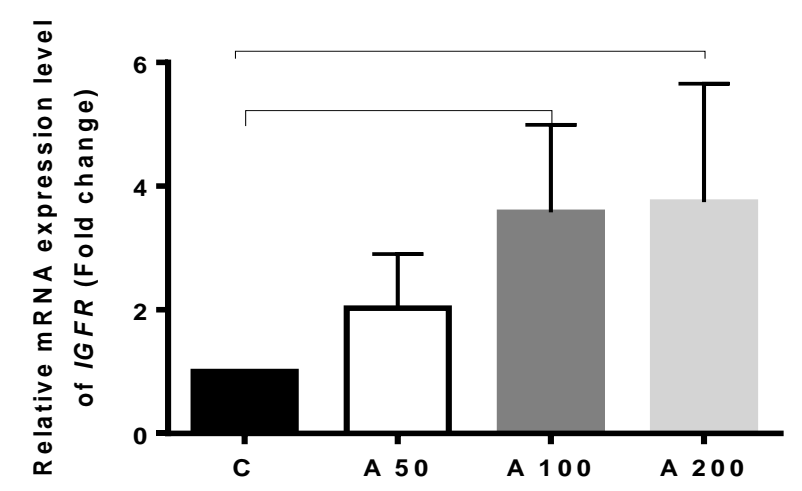

Figure 2. Relative mRNA expression level of IGFR (fold change). $\mathrm{C}$ group received $0 \mathrm{mg}$ alpha-lipoic acid (ALA) $/ \mathrm{kg}$ diet, A50 group received 50mg ALA $/ \mathrm{kg}$ diet, A100 group received $100 \mathrm{mg}$ ALA $/ \mathrm{kg}$ diet, and A200 group received 200mg ALA/kg diet.

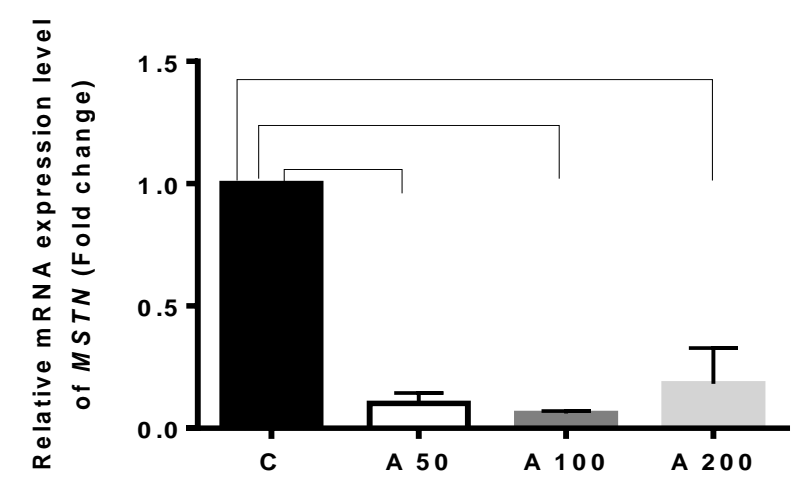

Figure 3. Relative mRNA expression level of MSTN (fold change). $\mathrm{C}$ group received $0 \mathrm{mg}$ alpha-lipoic acid (ALA) $/ \mathrm{kg}$ diet, A50 group received $50 \mathrm{mg}$ ALA $/ \mathrm{kg}$ diet, A100 group received $100 \mathrm{mg}$ ALA $/ \mathrm{kg}$ diet, and A200 group received 200mg ALA/kg diet.

\section{DISCUSSION}

Growth performance parameters significantly improved with dietary supplementation of ALA. These results may be attributed to the ability of the ALA to regulate energy metabolism where it is an integral component of mitochondria (Bai et al., 2012). Also, it has an antioxidant effect and acts as a coenzyme in carbohydrate metabolism in broilers (Packer et al., 2001). These results are consistent with findings of Guo et al. (2014) and Yoo et al. (2016) who reported improvement of birds' growth following ALA supplementation. Also, Lu et al. (2017) reported that ALA supplementation to broilers under ammonia stress could relieve stress status and restore production performance to normal levels. On the other hand, El-Senousey et al. (2013) and Zhang et al. (2014) reported that the supplementation of ALA to broiler's diet can lower weight gain and feed intake.

To deeply understand the mechanistic regulation of ALA to birds' growth, the relative mRNA levels of growth-regulating genes of GHR, IGFIR, and MSTN were measured for the first time in muscle tissues. Dietary supplementation of ALA significantly up-regulated the gene expression level of GHR, and IGFIR, while downregulated the mRNA level of MSTN. Modulating the expression level of these genes might explain the improved effect of the ALA on the birds' growth performance. Since, higher growth performance is positively correlated with higher levels of growth hormone and IGF1 (Wen et al., 2014). Thus, the upregulations of the gene expression level of $I G F I R$ and GHR perhaps are a good confirmation of the improving effect of the ALA to birds' growth. Where, IGF-1 stimulates the birds' growth by increasing the rate of protein synthesis in the skeletal muscle (Boschiero et al., 2013). Consequently, the upregulation of $I G F I R$ and $G H R$ is often positively correlated with the increase in body weight following the ALA dietary supplementation. This effect might be explained by the increased levels of total protein, albumin, and globulin levels. On the other hand, ALA downregulated the MSTN gene expression level which probably is associated with the improved effects on growth performance. The myostatin which belongs to the transforming growth factor $\beta$ (TGF- $\beta$ ) superfamily is a powerful negative regulator of muscle growth and differentiation (Jia et al., 2016). Thus, the higher expression of MSTN reduces the muscle fibers growth by downregulating myogenic differentiation factor (MyoD) and myogenic factor (Myf) expression level. Therefore, 
the reduction of MSTN expression level following ALA dietary provision can explain the improving effect on growth performance.

In general, biochemical constituents of the serum reflect the health, nutrition, climate, and management conditions to which the animals are submitted (Minafra et al., 2010). The levels of biochemical parameters in the serum can be used as an indication of the productive performance of the birds and of metabolic diseases (Rotava et al., 2008). The liver injury could increase the concentrations of many serum enzymes such as AKP, AST, and ALT (Shanmugarajan et al., 2008) and decrease the concentration of total plasma proteins, as the liver is the organ that synthesizes proteins, especially albumin (Schmidt et al., 2007). In the present study, the result of biochemical parameters significantly improved at the different inclusion rates of ALA compared to the control group. This present finding is strongly supported by the work of Li et al. (2014). Disagree with the finding of Kim et al. (2015) who reported that the level and source of ALA didn't affect total protein, albumin, and globulin but decreased the liver enzymes in the serum. The results of this trial may be attributed to the role of ALA as a biological thiol antioxidant (Ahmad et al., 2018). Normally, free radicals produced in the body under normal physiological conditions and removed by antioxidants. The balance between antioxidant and free radicals negatively affected by sub-optimal diets and poor nutrient intakes or positively affected by dietary supplementation (Surai, 2007). Based on the result of liver function-related parameters it can be concluded that ALA supplemented in the diet at these levels has no bad effect on broilers.

The results of the present study showed the beneficial effect of ALA on bone efficiency as indicated by increasing ash and calcium contents in tibia bone. It is well known that there is a direct relationship between liver and kidney functions and bone efficiency through activation of vitamin D by hydroxylation (Koreleski and Swiatkiewicz, 2005). In the present study, ALA improved liver function as indicated by the reduction of serum ALT and AST enzymes. On the other hand, reactive oxygen species such as hydrogen peroxides, the hydroxyl group, and superoxide interact with nucleic acid altering cellular metabolism leading to oxidation of hepatocytes or accumulation of fat (Karaman et al., 2010), where activation of vitamin D takes place. ALA acts as an antioxidant that protects hepatocytes and renal cells against oxidative stress (Guo et al., 2014). This function was reflected in increasing calcium deposition in bone, subsequently increasing ash content and bone density. The best dose of ALA in the diets of broiler chickens increasing bone efficiency was $100 \mathrm{mg} / \mathrm{kg}$ diet. Is there a direct relation between ALA and calcium deposition in bone? A question needs further investigation. More certainly, groups fed lipoic acid had significantly lower serum alkaline phosphatase activity than the control group. Decreasing the level of serum alkaline phosphatase activity reduced bone abnormalities and increased bone breaking strength (Ebrahimzadeh et al., 2013). From the literature, this study was the first one investigating the effect of dietary ALA supplementation on bone mineralization of broiler chickens.

\section{CONCLUSION}

In conclusion, ALA-supplemented diet resulted in significant improvements in the growth performance through regulating the liver functions, as well as growthregulating genes and bone efficiency in broilers.

\section{DECLARATIONS}

\section{Authors' contribution}

Osama A. Sakr and Eldsoky Nassef prepared diet formula and measured growth parameters. Sabreen Ezzat Fadl measured serum biochemistry and made interpretation of the results. Seham El-Kassas measured gene expression and made interpretation of the results. Hazem Omar and Emad Waded helped in the measuring of serum biochemistry.

\section{Conflicting interests}

No conflict of interest

\section{REFERENCES}

Ahmad SB, Ahmad I, Ahmad N, Qureshi ZI, Jamil H, Ali Q and Ashfaq K (2018). effect of addition of different concentrations of alpha lipoic acid to tris egg yolk citrate glycerol extender on cryopreservation of sahiwal bull spermatozoa. Pakistan Veterinary Journal, 38(3): 301-305. DOI: http://dx.doi.org/10.29261/pakvetj/2018.060.

AOAC. Association of Official Analytical Chemists (2019). Official Method of Analysis. 18th ed. AOAC, Gaithersburg, MD. Available at: https://www.aoac.org/official-methods-of-analysis-21stedition-2019/

Bai SW, Chen CY, Ji J, Xie QM, Ma Y, Sun BL, Xue CY, Cao YC, Ma JY and Bi YZ (2012). Inhibition effect of alphalipoic acid on the propagation of influenza $A$ virus in MDCK cells. Pakistan Veterinary Journal, 32(1): 101-106. Available at: www.pvj.com.pk. 
Boschiero C, Jorge EC, Ninov K, Nones K, do Rosário MF, Coutinho LL, Ledur MC, Burt DW and Moura AS (2013). Association of IGF1 and KDM5A polymorphisms with performance, fatness and carcass traits in chickens. Journal of Applied Genetics, 54(1):103-12. DOI: https://doi.org/10.1007/s13353-012-0129-6.

Chen J, Wang M, Kong Y, Ma H, and Zou S (2011). Comparison of the novel compounds creatine and pyruvate on lipid and protein metabolism in broiler chickens. Animal, 5 (7): 1082-1089.

DOI: https://doi.org/10.1017/s1751731111000085

Dushyanth K, Bhattacharya TK, Shukla R, Chatterjee RN, Sitaramamma T, Paswan C and Guru Vishnu P (2016). Gene expression and polymorphism of myostatin gene and its association with growth traits in chicken. Animal Biotechnology, 27(4):269-77. https://doi.org/10.1080/10495398.2016.1182541

DOI:

Ebrahimzadeh S, Farhoomand P and Noori K (2013). Effects of chromium methionine supplementation on performance, carcass traits, and the $\mathrm{Ca}$ and $\mathrm{P}$ metabolism of broiler chickens under heat-stress conditions. Journal of Applied Poultry Research, 22: 382-387. DOI: https://doi.org/10.3382/japr.2011-00506

El-Kassas S, Abdo SE, El-Naggar K, Abdo W, Kirrella AA and Nashar TO (2018). Ameliorative effect of dietary supplementation of copper oxide nanoparticles on inflammatory and immune responses in commercial broiler under normal and heat-stress housing conditions. Journal of Thermal Biology, 78:235-46. DOI: https://doi.org/10.1016/j.jtherbio.2018.10.009

El-Kassas S, Odemuyiwa S, Hajishengallis G, Connell TD and Nashar TO (2016). Expression and regulation of cholecystokinin receptor in the chicken's immune organs and cells. Journal of Clinical and Cellular Immunology, 7(6): 471. DOI: https://doi.org/ 10.4172/21559899.1000471

El-Senousey HK, Fouad AM, Yao JH, Zhang ZG and Shen QW (2013). Dietary alpha lipoic acid improves body composition, meat quality and decreases collagen content in muscle of broiler chickens. Asian-Australasian Journal of Animal Sciences, 26(3):394. DOI: 10.5713/ajas.2012.12430

Guo ZY, Li JL, Zhang L, Jiang Y, Gao F and Zhou GH (2014). Effects of alpha-lipoic acid supplementation in different stages on growth performance, antioxidant capacity and meat quality in broiler chickens. British Poultry Science, 55(5):635-43.

DOI: https://doi.org/10.1080/00071668.2014.958057

Jia Y, Gao G, Song H, Cai D, Yang X and Zhao R (2016). Lowprotein diet fed to crossbred sows during pregnancy and lactation enhances myostatin gene expression through epigenetic regulation in skeletal muscle of weaning piglets. European Journal of Nutrition, 55(3):1307-14. DOI: https://doi.org/10.1007/s00394-015-0949-3

Kamel ER, Manaa E and Farid AS (2016). The effects of dietary date pit on the productive and economic efficiency of Japanese quail. Alexandria Journal of Veterinary Science, 51(2):211-222. DOI: https://doi.org/10.5455/ajvs.233838

Karaman M, Özen H, Tuzcu M, Ciğremiş Y, Önder F and Özcan K (2010). Pathological, biochemical and haematological investigations on the protective effect of $\alpha$-lipoic acid in experimental aflatoxin toxicosis in chicks. British Poultry Science, 51(1):132-41. DOI: https://doi.org/10.1080/00071660903401839

Kim DW, Mushtaq MM, Parvin R, Kang HK, Kim JH, Na JC, Hwangbo J, Kim JD, Yang CB, Park BJ and Choi HC (2015). Various levels and forms of dietary $\alpha$-lipoic acid in broiler chickens: Impact on blood biochemistry, stress response, liver enzymes, and antibody titers. Poultry Science, 94(2):226-31. DOI: https://doi.org/10.3382/ps/peu056

Kofuji K, Nakamura M, Isobe T, Murata Y and Kawashima S (2008). Stabilization of $\alpha$-lipoic acid by complex formation with chitosan. Food Chemistry, 109(1):167-71. DOI: https://doi.org/10.1016/j.foodchem.2007.11.078

Koreleski J and Świątkiewicz S (2005). Efficacy of different levels of a cholecalciferol 25-OH-derivative in diets with two limestone forms in laying hen nutrition. Journal of Animal Feed Science, 14(2): 305-315. DOI: https://doi.org/10.22358/jafs/67018/2005

Li Y, Ma QG, Zhao LH, Guo YQ, Duan GX, Zhang JY and Ji C (2014). Protective efficacy of alpha-lipoic acid against aflatoxinB1-induced oxidative damage in the liver. AsianAustralasian Journal of Animal Sciences, 27(6):907. DOI: https://doi.org/10.5713/ajas.2013.13588Livak KJ and Schmittgen TD (2001). Analysis of Relative gene expression data using real-time quantitative PCR and the 2- $\triangle \Delta \mathrm{CT}$ method. Methods, 25, 402-408. DOI: https://doi.org/10.1006/meth.2001.1262

Lu M, Bai J, Wei F, Xu B, Sun Q, Li J, Wang G, Tang X, Zhang H, Yin Q and Li S (2017). Effects of alpha-lipoic acid supplementation on growth performance, antioxidant capacity and biochemical parameters for ammonia-exposed broilers. Animal Science Journal, 88(8):1220-5. DOI: https://doi.org/10.1111/asj.12759

Minafra CS, Marques SF, Stringhini JH, Ulhoa CJ, Rezende CS, Santos JS and Moraes GH (2010). Perfil bioquímico do soro de frangos de corte alimentados com dieta suplementada com alfa-amilase de Cryptococcus flavus e Aspergillus niger HM2003. Revista Brasileira de Zootecnia, 39(12):2691-2696. DOI: http://dx.doi.org/10.1590/S1516-35982010001200020

Packer L, Witt EH and Tritschler HJ (1995). Alpha-lipoic acid as a biological antioxidant. Free Radical Biology and Medicine, 19:227-250. DOI: https://doi.org/10.1016/08915849(95)00017-R

Packer L, Kraemer K and Rimbach G (2001). Molecular aspects of lipoic acid in the prevention of diabetes complications. Nutrition, 17: 888-895. DOI: https://doi.org/10.1016/S0899-9007(01)00658-X

Petracci M and Cavani C, 2012. Muscle growth and poultry meat quality issues. Nutrition, 4(1): 1-12. DOI: https://doi.org/10.3390/nu4010001

Rotava R, Zanella I, Karkow AK, Dullius AP, da da Silva LP and Denardin CC (2008). Bioquímica sanguínea de frangos de corte alimentados com subprodutos da uva. Agrarian, 1(1):91-104. Available at: http://www.uvibra.com.br/ pdf/safra_uva1998-2007.pdf. 
Schmidt EMS, Locatelli-Dittrich R, Santin E and Paulillo AC (2007). Patologia clínica em aves de produção-uma ferramenta para monitorar a sanidade avícolarevisão. Archive of Veterinary Science, 12(3). DOI: https://doi.org/10.5380/avs.v12i3.10906

Shanmugarajan TS, Sivaraman D, Somasundaram I, Arunsundar M, Krishnakumar E, Balaji R and Ravichandiran V (2008). Influence of alpha lipoic acid on antioxidant status in Dgalactosamine-induced hepatic injury. Toxicology and Industrial Health, 24(10):635-42. DOI: https://doi.org/10.1177/0748233708101215

Sohaib M, Anjum FM, Nasir M, Saeed F, Arshad MS and Hussain S (2018). Alpha-lipoic acid: An inimitable feed supplement for poultry nutrition. Journal of Animal Physiology and Animal Nutrition, 102(1):33-40. DOI: https://doi.org/10.1111/jpn.12693

Surai PF (2007). Natural antioxidants in poultry nutrition: new developments. In Proceedings of the 16th European symposium on poultry nutrition (pp. 26-30). World Poultry Science Association.
Wen C, Wu P, Chen Y, Wang T and Zhou Y (2014). Methionine improves the performance and breast muscle growth of broilers with lower hatching weight by altering the expression of genes associated with the insulin-like growth factor-I signaling pathway. British Journal of Nutrition, 111(2):201-6.

DOI: https://doi.org/10.1017/S0007114513002419

Yoo J, Yi YJ, Koo B, Jung S, Yoon JU, Kang HB, Lee DH and Heo JM (2016). Growth performance, intestinal morphology, and meat quality in relation to alpha-lipoic acid associated with vitamin $\mathrm{C}$ and $\mathrm{E}$ in broiler chickens under tropical conditions. Revista Brasileira de Zootecnia, 45(3):113-20. DOI: http://dx.doi.org/10.1590/S180692902016000300005

Zhang Y, Jia R, Ji C, Ma Q, Huang J, Yin H and Liu L (2014). Effects of dietary alpha-lipoic acid and acetyl-L-carnitine on growth performance and meat quality in Arbor Acres broilers. Asian-Australasian Journal of Animal Sciences, 27(7):996. DOI: https://doi.org/10.5713/ajas.2013.13436 